\title{
Diffusion of ICTs and E-commerce adoption in manufacturing SMEs in Kenya
}

\author{
S.O. Migiro' \\ Department of Business Management and Department of Library and Information Science, \\ University of Zululand, 24169 Kwadlangezwa 3886, South Africa \\ migirostephen@yahoo.com
}

Received: 7th November 2005

Accepted: $31^{\text {st }}$ January 2006

\begin{abstract}
The Internet's World Wide Web has become the prime driver of modern E-commerce. The World Wide Web and the Internet together with other ICT enabling technologies offer a platform in the way organizations arrange their business processes, address their marketplaces, and partner with other enterprises. The objectives of this paper are to map ICT diffusion and adoption of e-commerce by manufacturing SMEs in Kenya and identify specific barriers to the exploitation of these drivers. The investigation adopts a descriptive survey research design in which random sampling techniques are used. The data was analysed using descriptive statistics. Results reveal that high cost, limited funds and lack of technical know-how are barriers in the diffusion of ICTs among the manufacturing SMEs.
\end{abstract}

Keywords: E-commerce, ICTs, SMEs, Kenya

\section{Introduction}

In most developing and developed countries, small and medium enterprises (SMEs ) comprise 90 per cent of all enterprises. For example, according to the Organisation of Economic Corporation and Development (OECD, 2002), SMEs represent between 96 and 99 per cent of the total number of enterprises in most OECD countries. However, SMEs are defined differently between countries and within sectors. Definitions differ in the break points they employ, and also in the underlying basis used for classification (Ayyagari , Beck and Demirguc-Kunt, 2003:4). Some of these definitions are based on quantitative measures such as number of employees, turnover or total investment in assets, while others employ a qualitative approach that reflects how the business is organised and how it operates. For example, SMEs are deemed to be independently owned and operated and not dominant in their fields of operation (Bunker \& MacGregor, 2000; Dennis, 2000; MacGregor \& Vrazalic, 2004:2).

In the Kenyan context, small enterprises are those businesses that have 9-49 employees, whereas medium enterprises are those businesses that have 49-99 employees. Those firms which engage less than five employees are referred to as micro enterprises (Republic of Kenya, 1986). Developing countries are dominated by micro and small enterprises (MSEs) as the sector is often characterized by a "missing middle" (UNIDO, 2002:5). This state was confirmed from the current investigation without prior design or deliberate choice.

Such firms, the majority of which are family controlled, make a major contribution to private sector employment and income. For example, in 2004, the modern sector created 36,400 extra jobs in Kenya while the informal sector created 437,900 more jobs [CBS, 2005].

However, despite their contribution to Job creation, SMEs in Kenya function with limited access to markets, finance and new technology. With limited access to technology, SME productivity remains significantly low. Hence, there appear to be relatively few examples of Kenyan SMEs which have sustained growth to a global position due to reasons such as lack of technical knowledge and information technology specialist staff, informal and inadequate planning Processes, limited share of the market share and centralised management with a short range Perspective (Quayle, 2002; Martin \& Matlay ,200I; Tetteh \& Burn, 200I; Miller \& Besser, 2000 ).

For the sector to expand and reduce poverty and income disparities, it is imperative that it embraces changes in the global technological environment and strive to reach international markets. Largely, the sector is challenged by the globalization of production and the shift in the importance of the various determinants of competitiveness. Through the rapid spread of information and communication technologies (ICTs), markets in different parts of the world have become more integrated. Hence, to achieve expected competitiveness, adoption of electronic commerce (E. commerce) and drivers is invaluable. For example, e-commerce is facilitated by ICT tools such as the Internet, the World Wide Web (WWW), wireless mobile phones, telefax and computers, among other tools. ICTs facilitate the production, processing and transmission of information. They are often lauded as catalyst for development in modern society. Thus the question

I. Stephen Migiro is a PhD student at the University of Zululand and also a Lecturer in Business Management, Moi University, Kenya 
whether these technologies can help SMEs overcome their disadvantages and contribute to overall growth and export performance becomes important (Michiels and Van Crowder, 2001:8).

Electronic commerce is defined by the dynamics of the Internet. Electronic commerce was recognised with the invention of the World Wide Web combined with the pre-existing capabilities of the Internet to offer a platform for innovation in the way organizations arrange their business processes, address their marketplaces, and partner with other enterprises. Electronic commerce is defined as: the conduct of commerce in goods and services, with the assistance of telecommunications and telecommunications-based tools (Raymond, 200I: 4II). It is the automation of commercial transactions using computer and communications technologies (Westland and Clark, 1999). Turban et al (2002: 4) define e-commerce as: "the exchange of information across electronic networks at any stage in the supply chain, whether within an organization, between business and consumers or between public and private sectors. It is described as the use of electronic networks, the Internet, mobile or digital technology for the successful exchange of information, buying and selling of products and services and online payments by the electronic transfer of funds (Reedy, Schullo and Zimmerman, 2000:4).

In conclusion, the world's economy has been characterized by increasing globalisation. Precisely what this means is that markets are now global, and that everywhere large and small firms have equal access to markets that span the world. Moreover, it is also suggested that such activity is increasingly fuelled by access to the internet and the use of electronic payment systems. Thus, the purpose of this paper is to map the diffusion of e-commerce and e-commerce enabling technologies among manufacturing SMEs in Kenya and identify barriers to adoption.

\section{Statement of the problem, purpose and objectives}

SMEs are an important sector of all economies of the world. The sector plays an important role in the development of infrastructure by providing employment, innovation and wealth creation. The implementation of new technologies, use of ICT (information and communication technologies) and electronic commerce in SMEs provides numerous organizational opportunities. Unfortunately, despite advances in information technology and acceptance by large organisations of such technologies, the same level of adoption is not evident amongst SMEs (Knol \& Stroeken 200I). The benefits of e-commerce are not only for large firms; small and medium sized enterprises (SMEs) can also benefit from e-commerce [Chen et al, 2003]. E-commerce levels the playing field with big business, provide location and time independence, and ease communication (Longenecker et al., 1997; lacovou et al. 1995). Akkeren and Cavaye (1999) state that e-commerce improves an SME's ability to compete with larger organizations and operate on an international scale. They also see ecommerce as a tool for providing cost-effective ways for SMEs to market their business, launch new products, improve communications, gather information, and identify potential business partners (Akkeren and Cavaye, 1999). However, in spite of the many potential advantages of e-commerce, its adoption by SMEs remains limited. For example, a survey conducted by Verizon [Cyber Atlas, 200I] found that $36 \%$ of small businesses established web sites primarily to advertise and promote their business, compared to $9 \%$ who established one to sell or market online. Also, in a survey of 444 SMEs (Pratt, 2002] found that more than $80 \%$ SMEs were only using the Internet to communicate (via e-mail) and gather business information.

Participation in e-commerce is important from the perspective of commercial transactions but more so in the way it encourages transformation of internal systems and the subsequent influences in terms of cost, responsiveness to customers, customization of offerings and the potential emergence of new products and services (Crawford 1998:.6). However, most SMEs adopt e-commerce in a just by chance manner, rather than as a consequence of systematic consideration and planning (Engsbo 200I; Scupola 2002). From this viewpoint it is considered that the study of ecommerce adoption by SMEs in Kenya is important as it will shed light on the current situation. Accordingly, this research was interested in exploring the extent of the e-commerce usage in SMEs in Kenya, identify factors influencing EC adoption and establish the uptake of ICTs. Thus, the research objectives were to:

I. Map the diffusion of ICTs;

2. Map adoption of e-commerce among manufacturing SMEs; and

3. Identify factors that influence the adoption of e-commerce among manufacturing SMEs in Kenya.

\section{Literature review}

SMEs (both in the developed and developing worlds) all share a common interest in making their businesses more efficient, lucrative, and sustainable. Technology could be used to achieve these goals. But SMEs require access to such technologies to even know of their existence, much less to understand what they can provide for business operations. Adoption of e-commerce within the SME community is considered to be a means to enable these businesses to compete on a global scale, with improved efficiency, and closer customer and supplier relationships (Kagami and Tsuji, 200I; Seyal 
and Tazrajiman, 2003). Despite the potential benefits of ICT and e-commerce, there is debate about whether and how their adoption improves firm performance. Use of and investment in ICT requires complementary investments in skills, organization and innovation. Many studies point to the possibility of market expansion as a major benefit for SMEs. However, it is not easy for SMEs to implement and operate an on-line business, as this involves complementary costs for training and organisational changes as well as direct costs of investing in hardware and software solutions (Khan and Khan, 1992; Seyal, 2003). Nevertheless, empirical work by researchers in I 3 OECD countries based on large scale statistical surveys provide evidence that the use of ICT can contribute to improved firm performance, in terms of increased market share, expanded product range, customised products and better response to client demand (OECD, 2004).

Nonetheless, the majority of studies undertaken to date in the e-commerce domain have addressed the specific context of large enterprises. Fewer studies have been carried out in the specific context of SMEs. However, the importance of the SME sector is leading to a steady growth in studies of e-commerce adoption by such firms. Poon and Jevons (1997) were amongst the first to recognize the potential benefits that the Internet offered SMEs, suggesting that it creates an unprecedented opportunity for small businesses to engage in national and international marketing campaigns that previously would have been unaffordable (Poon and Jevons 1997: 29). Hamill and Gregory (I997) also recognized the role the Internet could play in the internationalization of SMEs and stressed that lack of adoption would result in a decline in their competitive position. Sillince et al. (1998) explored the role of e-commerce in improving communication in a study of e-mail adoption in the specific context of SMEs. They found that e-mail use resulted in effeciency gains and the ability to perform new tasks, such as sharing documents and working remotely, findings consistent with the exploratory study of e-commerce in SMEs undertaken by Poon and Swatman (1999). Dutta and Evrard (1999) found that SMEs were using the Internet for a number of distinct activities such as improved communication, access to information, marketing and transactions with customers and suppliers. These findings have been reinforced and extended by other studies of SME adoption of e-commerce, such as those by Jacobs and Dowsland (2000), Doherty et al. (200I) and Daniel et al. (2002).

Other e-commerce (EC) studies have indicated the high adoption rate of EC technologies by businesses in different parts of the world. Most of these studies described the high adoption rate of EC technologies as an indication of EC capability and superiority, (Ministry of Economic Development (MOED), 2000b). However, these studies did not show the extent of EC usage in the business environment of these enterprises, dominated mostly by Small to Medium-Sized Enterprises (Nielsen, 200 I; Deloitte, 2000). For example, while the New Zealand Government reported the widespread adoption of the technologies that enable EC, it was suspicious of the depth of their penetration and ability to support fully integrated electronic business systems (MOED, 2000b).

A Eurostat survey (200I) on e-commerce shows that nine out of ten SMEs were equipped with computers at the end of 2000. Internet access is also commonplace among SMEs. While Internet penetration is generally higher in larger enterprises, the gap between larger firms and SMEs is narrowing. In most OECD countries, Internet penetration rates for medium-sized firms (50-249 employees) are the same and sometimes higher than for larger firms (more than 250 employees), with penetration rates of over $80 \%$, although there are exceptions. Small firms (I0-49 employees) have a slightly lower penetration rate, between $60 \%$ and $90 \%$. Even in micro-enterprises, the penetration rate is nearly $60 \%$ in most countries and in Denmark 85\% have Internet access (OECD, 2004)

Yet, in the less developed countries, many SMEs appear reluctant to embrace e-commerce applications. The main reasons cited for this reluctance are, lack of awareness, lack of business opportunities, lack of strategic vision and lack of realisation of benefits of e-commerce to individual SMEs (Crawford ,1998:.20). Besides, extant studies have argued that most SMEs lack technical expertise (Barry \& Milner 2002), most lack adequate capital to undertake technical enhancements (Raymond, 200I), most SMEs suffer from inadequate organisational planning (Tetteh \& Burn, 200I; Miller \& Besser, 2000) and many SMEs differ from their larger counterparts in the extent of the product/service range available to customer (Reynolds et al., 1994). In addition, Matlay (2000:137) has shown that the business sector is significantly associated with e-commerce adoption.

A number of other studies have been carried out to determine which business characteristics may affect adoption of e-commerce by SMEs. Hawkins et al. (1995) and Hawkins and winter (1996), have noted that because SMEs are diverse in nature, results are not generalisable across the entire SME sector. Fallon and Moran (2000) found significant links between the business size of the SME in terms of the number of employees and the level of internet adoption. Matlay (2000) showed that the business sector was significantly associated with e-commerce adoption. These studies showed that smaller SMEs (fewer than 10 employees) were less likely to adopt e-commerce technology than larger SMEs. They also found that service organisations were more likely to adopt e-commerce than manufacturing or retail based SMEs. Riquelme (2002), in a study of 75 Chinese SMEs found that those involved in service tended to adopt e-commerce far more than their manufacturing counterparts. Blackburn and Athayde (2000) identified not only business size and business

SA Jnl Libs \& Info Sci 2006, 72(I) 
sector but also the level of international marketing as a business characteristic associated with adoption of e-commerce technology. As with the pre-e-commerce adoption of IT, a number of studies (Tetteh \& Burn, 200I; O'Donnell et al., 200I) have concluded that successful e-commerce adoption is associated with both the level of IT skill within the SME as well as with the development, prior to e-commerce adoption, of business wide systems.

Furthermore, SMEs are more reluctant to spend on information technology and therefore have limited use of technology (Walczuch et al., 2000;Dennis ,2000; MacGregor and Bunker , 1996b ; Poon and Swatman , 1997 and Abell and Limm , 1996). Notwithstanding findings from these studies, other studies have looked at the reasons SMEs adopt e-commerce technologies (i.e ICTs) and the factors that affect its adoption (Sharma and Gupta, 2003; Mehrtens et al. 200I:I72 and Korchak and Rodman, 200I:23). Like their larger counterparts, SMEs look to e-commerce as a means of improving sales (Abell and Limm 1996), improving marketing (Poon and Swatman 1997:7-9; Seyal, 2003), reaching new customers and markets (Ritchie and Brindley 2001:579, Vescovi 2000:109), and improving overall efficiency (Tetteh and Burn 200 I: 176-78). According to Neergaard (1992), there are four main reasons for the acquisition of information technology by SMEs. These are increased productivity, streamlining work procedures, better client service and better record keeping.

Nevertheless, SME managers are still not convinced that E-commerce fits the products or services that their businesses offer. Studies by Bakos and Brynjolfsson (2000), Sawhney and Zabin (2002), and Merhtens et al. (200I) have found that there is still reluctance for SME managers to adjust their businesses to the requirements and demands placed on it by E-commerce participation.

\section{Method and procedure}

The idea of innovation is about presenting adopters with new ideas or means of solving problems. This study was informed by Roger's Innovation and Diffusion theory. Rogers (1983, 1995) suggests that those innovations which are perceived by individuals as having greater relative advantage, compatibility, trialability and observability will be adopted more rapidly than those which are perceived as more complex. Rogers proposed a model of the innovation-decision adoption process that emphasizes the role of individual behavior in the technology adoption process (see Figure I). The model relates actions and choices during which an individual evaluates a new innovation and decides whether or not to incorporate it into an ongoing practice.

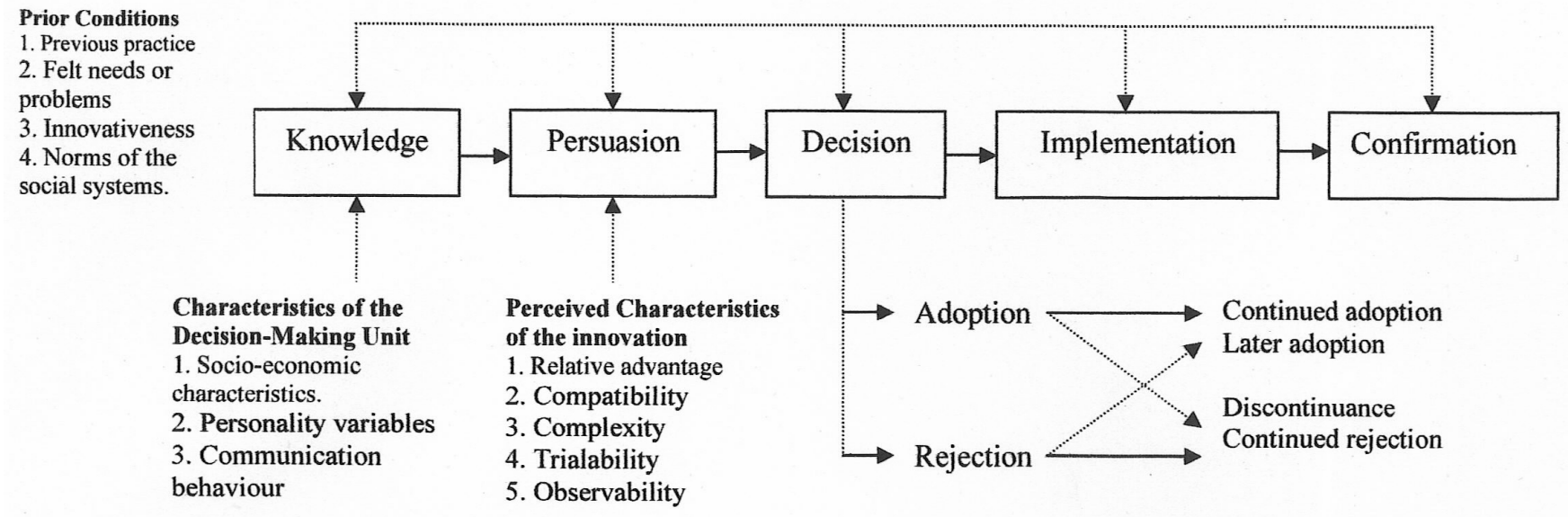

Source: Roger (1995:163), “Innovation - Decision Process”

Figure 1 The model of the innovation-decision process

Roger's framework was found useful as the paper sought to understand the diffusion and use of modern ICTs by manufacturing SMMEs in the investigation.

To this end, the study target was manufacturing SMEs located within Nairobi, Nakuru, Kisumu and Eldoret, Kenya. The locations were chosen for their diverse manufacturing activities and concentration of enterprises in metal and metal products, Textile and garment and Wood and wood products. The population of the respondents consisted of 940 SMEs registered with respective business associations in the sub-sectors in the investigation. Applying random and stratified sampling, a sample size of 380 respondents was selected for the study. These sampling techniques helped to control for bias in the selection process. The respective sub-sector sample sizes were: Textile and garment (119) respondents, Metal and metal products (152) respondents and Furniture and wood products (109) respondents, adding to three hundred and 
eighty respondents. To collect empirical data, a survey research design was used in which questionnaires were randomly administered. The instrument sought information about enterprise and personal characteristics of the operators, as well as the use of ICTs and adoption of E-commerce.

Table I Sample, $\mathrm{s}=380$ and population $\mathrm{N}=940$.

\begin{tabular}{lccccc}
\hline Textile & \multicolumn{5}{c}{} \\
\hline Towns & Nairobi & Nakuru & Kisumu & Eldoret & Total \\
$\mathrm{N}$ & 180 & 15 & 45 & 10 & 250 \\
$\mathrm{~S}$ & 65 & 13 & 31 & 10 & 119 \\
\hline Metal & 397 & 18 & 55 & 26 & 496 \\
\hline $\mathrm{N}$ & 80 & 15 & 36 & 21 & 152 \\
$\mathrm{~S}$ & & & & & \\
\hline Furniture & 102 & 20 & 55 & 5 & 182 \\
\hline $\mathrm{N}$ & $5 \mathrm{I}$ & 17 & 36 & 5 & 109 \\
$\mathrm{~S}$ & & & & &
\end{tabular}

4.1 E-commerce Measurement variables

E-commerce adoption was measured by internet access, use of website, online marketing, use of the web for buying and selling, sending e-mail to communicate with business partners, using the World Wide Web to access information such as information about markets and competitors; and use of ICT tools for business information processing.

4.2 Data analysis

Descriptive statistics was used to analyse and present empirical data. To facilitate the analysis, items in the research instrument were measured using the Likert Scale of I to 5, where," very essential" and "strongly agree" scored "5", and "never" or "poor" scored "I".

\section{Results}

This section presents the empirical results on enterprise profile, ICT diffusion, e-commerce adoption, and barriers to ecommerce adoption.

\subsection{Enterprise profile}

From the empirical results, 312 or $82.1 \%$ of the manufacturing SME operators were male while 68 or $17.9 \%$ were female. As concerns form of business ownership, the study found that majority of the enterprises in the survey were sole proprietorships 233 or $61.3 \%$. However, 48 or $51.1 \%$ of the textile enterprises and 32 or $34 \%$ of the metal enterprises were in the form of partnerships. Eighty-eight percent of the enterprises had less than 10 employees. Majority of the firms 314 or $82.7 \%$ have been in existence for over three years. Enterprises were found to be slightly older in furniture and metalwork sub-sectors. It was further found that most of the manufacturing SME owners had secondary education: textile $6 \mathrm{I}(5 \mathrm{I} .3 \%)$, furniture $48(44 \%)$ and metal 73 (48\%). However, the number of university graduate operators in the sample was insignificant. The survey found only one postgraduate operator in the metal industry and three graduates each in the textile and furniture industries respectively. .

5.2 Information and communication technology usage

This section provides empirical results on the first objective on the diffusion of ICTs among the respondents. It was found that, out of three hundred and eighty respondents, only 25 or $6.6 \%$ had used computers for more than 2 years. The respondents rated their information technology skills as below average. Majority of the respondents (205 or 54\%) of the respondents indicated that they used information technology consultants to handle their computing requirements, while 175 or $46 \%$ thought that use of computers in the business was not necessary. None of the respondents had developed a web site and II or $2.9 \%$ had adopted e-commerce. Table 2 shows the extent to which the various types of ICTs were used. Overall, the levels of use of the various kinds of ICTs is quite low with 97.4 percent of all respondents not having Internet connection, 100 percent not having a website, and 2.9 percent using some form of e-commerce.

The respondents were asked to rate the extent to which different kinds of ICTs were used in their enterprises. To measure their responses, a binary choice of $\mathrm{I}=$ yes and $\mathrm{No}=2$ was used. Of the total respondents, $65 \%$ or 247 enterprises own and use cellular or mobile phones for business. However, $35 \%$ or 133 firms do not have and do not use cellular/mobile phones in their business. Of the 247 SMEs or $100 \%$ who own cellular phones, 200 firms or $80.9 \%$ use text messaging (SMS) for business purposes, such as communicating with customers, ordering from suppliers, and communication among employees among others. 
The use of the telefax machine is insignificant in the enterprises surveyed. Of the total firms in the sample, $1.6 \%$ or 6 enterprises have their own business facsimile machines. Nevertheless, the telephone is almost universal among the respondent-firms in this study. Only $26 \%$ or 98 enterprises do not have their own phone for business use. Thus, Computers, the Internet and fax machines were insignificantly used as evidenced in table 2 below.

Table 2 Information and communication technology usage $(\mathrm{N}=380)$

\begin{tabular}{lccccc}
\hline Type of ICT used & Mobile phone & Internet & Website & Computers & Fax machine \\
\hline Yes $(\%)$ & 65 & 2.6 & - & 6.6 & 1.6 \\
No. of respondents & 247 & 10 & - & 25 & 6 \\
No (\%) & 35 & 97.4 & 100 & 93.4 & 98.4 \\
No. of respondents & 133 & 370 & 380 & 355 & 374 \\
\hline
\end{tabular}

\subsection{E-commerce Adoption}

Table 3 shows the responses to the question relating to the second objective, "which of the following are your reasons for adopting e-commerce? To enable the respondents know what e-commerce is or mean in order to make informed judgement and provide reliable responses, the interviewer clarified the meaning of the term before they could provide their responses. After that, the respondents were provided with a list of possible reasons for e-commerce adoption and asked to rate each one on a scale of $I$ to 5 depending on how applicable it was to their situation $(I=$ not at all applicable; $2=$ slightly applicable; $3=$ neutral; $4=$ applicable; $5=$ very applicable). For the purposes of analysis, scores $I$ and 2 ; and 4 and 5 have been combined. Table 3 below shows the number of responses for each combination and the corresponding percentages.

An examination of the data shows that the most desired reason for adopting e-commerce was increased sales (a total rating of $78.9 \%$ at the combined level of 4 and 5); to reach new/ interact with customers (a total rating of $67.1 \%$ at the combined level of 4 and 5); and need to improve quality of information (a total rating of $67.1 \%$ at the 4 and 5 level) respectively.

Table 3 Reasons for Electronic commerce $(E C)$ adoption $(N=380)$

\begin{tabular}{l|cc|cc|cc}
\hline \multirow{2}{*}{ Possible reasons for EC adoption } & \multicolumn{7}{|c|}{ Combined scores } \\
\cline { 2 - 7 } & \multicolumn{2}{|c}{ I \& 2 } & \multicolumn{2}{c}{$\mathbf{3}$} & \multicolumn{2}{c}{$\mathbf{4 ~ \& ~ 5}$} \\
\cline { 2 - 7 } & No. & $\%$ & No. & $\%$ & No. & $\%$ \\
\hline Interaction with customers & 80 & 21 & 45 & 11.8 & 255 & 67.1 \\
Taking orders online & 132 & 34.7 & 48 & 12.6 & 200 & 52.6 \\
Increased sales & - & - & 80 & 21 & 300 & 78.9 \\
New customers/markets & 74 & 19.5 & 86 & 22.6 & 220 & 57.8 \\
Improvement in marketing & - & - & 145 & 38.1 & 235 & 61.8 \\
Improved quality of information & 65 & 17.1 & 90 & 23.7 & 225 & 67.1 \\
Increased internal efficiency & 65 & 17.1 & 155 & 40.8 & 160 & 42.1 \\
Improved competitiveness & 15 & 3.9 & 15 & 3.9 & 350 & 92.1 \\
\hline
\end{tabular}

About $85 \%$ of the respondents believe that e-commerce is at least important. With respect to the importance rating of ecommerce to the sample SME firms -:

- $167(44 \%)$ indicated that e-commerce is very important for business today

- $76(20 \%)$ say important

- $82(21.8 \%)$ say somewhat important

- $20(5.4 \%)$ are indifferent

- $33(8.8 \%)$ say that it is not important

\subsection{Barriers to e-commerce adoption}

Table 4 shows the responses to the question, "what are the perceived constraints to e-commerce adoption in your enterprise?" SMEs were provided with a research instrument having a list of possible barriers and asked to rate each one on a scale of $\mathrm{I}$ to 5 depending on how applicable it was to their situation ( $\mathrm{I}=$ not at all applicable; $2=$ slightly applicable; $3=$ neutral; $4=$ applicable; $5=$ very applicable). ). For analysis, scores I and 2 (=not applicable) and 4 and 5 (=applicable) have been combined. 
Most of the SMEs surveyed have not taken up e-commerce, let alone use the Internet, because they fail to see the value of e-commerce to their businesses. Many perceive ecommerce as something to be used only by large enterprises and that it is an additional cost that will not bring any major returns on investment. Besides, technology literacy is still very limited in Kenya. The respondents identified dearth of computer skills as a key issue in moving forward with using information technology in their businesses, 256 (67.3\%). In addition, cost is a crucial issue. The initial investment for the adoption of a new technology is proportionately heavier for small than for large enterprises. The respondents identified the high cost of computers and Internet access to be a barrier to the uptake of e-commerce, $350(92.1 \%)$. As a result, only $10(2.6 \%)$ use e-commerce, with reasons for not using e-commerce being cost, limited funds, lack of technical know-how and not sure what to adopt 347 (91.3\%). However, most of the respondents, 340 (89.5) were interested in receiving training in the application of ICTs in e-commerce.

Table 4 Current situation and barriers to e-commerce adoption

\begin{tabular}{l|cc|ccc|c}
\hline \multirow{2}{*}{ Perceived barriers } & \multicolumn{5}{|c}{ Combined scores } \\
\cline { 2 - 7 } & \multicolumn{2}{|c|}{ I \& 2 } & \multicolumn{2}{c}{$\mathbf{3}$} & \multicolumn{2}{c}{$\mathbf{4 ~ \& ~ 5 ~}$} \\
\cline { 2 - 7 } & No. & $\%$ & No. & $\%$ & No. & $\%$ \\
\hline Costs too high & - & - & 30 & 7.9 & 350 & 92.1 \\
Lack of technical know-how & 24 & 6.3 & 100 & 26.3 & 256 & 67.3 \\
Limited funds & - & - & 30 & & 350 & 92.1 \\
e-commerce tools don't fit our products or services & 278 & 73.1 & 80 & 21.1 & 22 & 5.8 \\
e-commerce doesn't fit the way we do business & 278 & 73.1 & 80 & 21.1 & 22 & 5.8 \\
Not sure what to adopt & 21 & 5.5 & 10 & 2.6 & 347 & 91.3 \\
\hline
\end{tabular}

\section{Discussions and conclusion}

Most of the enterprises in the study had not purchased computers and connected to the internet due to associated cost. Faced with budgetary constraints, SMEs consider the additional costs of ICT spending as too big an investment without immediate returns due to a lack of a critical mass of users. The investigation revealed that PC use is not dominant. Only $6.6 \%$ ( 25 enterprises) own and use personal computers or PCs, and of these, only $2.6 \%$ of the enterprises own PCs with Internet access, out of which $2 \%$ comprise textile and garment and wood and wood products. It however emerged that, SMEs' Perception on the importance of the Internet and E-Commerce was mixed. Most of the respondents believe that the Internet is at least somewhat important for business today. Specifically, $27 \%$ say that the Internet is very important for business today; $61 \%$ say it is important and $6 \%$ say somewhat important. Only $4 \%$ say it is not important at all, while $2 \%$ are indifferent. Nonetheless, the proportion of those who believe the Internet will be "very important" in the future is a remarkable $70.2 \%$ of total respondents. $11 \%$ say it is "important" for business in the future and $14.2 \%$ say it is "somewhat important". An insignificant $3.6 \%$ says it is not important at all, while $1.6 \%$ is indifferent.

The number of enterprises communicating through the Internet is rather low. It is a meagre $2.6 \%$ or 10 respondents out of a possible three hundred and eighty respondents. In face-to-face interviews, it was claimed that the main reason of this is that many enterprises are not aware of the benefits to be derived from the use of the internet in business transactions. Nonetheless, from these discussions, it was found that majority of the enterprises have the desire to use the Internet for business information. This compares well with the results of Smith. Boocock,, Loan-Clarke and Whittaker (2002) on a study on SME's awareness, benefits and barriers to adoption of e-commerce enabling technologies.

Cost of e-commerce tools was found to inhibit its adoption. As a result, the development of an effective web site was cited as an expensive undertaking by some of the respondents. It was reported that e-commerce activities such as purchase of computers and networking technologies need to be invested in. All these costs put together inhibited the manufacturing SMEs in the investigation from adopting e-commerce and its enabling tools. It further emerged from the face-to-face interviews that uptake of e-commerce was difficulty as customers and suppliers were not e-commerce compliant. This supports Chapman, James-Moore, Szczygeil and Thompson (2000), Chesher and Skok (2000) ; Mirchandani and Motwani (200I) and Sharma and Gupta(2003) findings that adoption of e-commerce is dependent on the adopters' level of technology skills and willingness to adopt new innovations in business.

A number of other factors that affect adoption of e-commerce tools have a relationship with the business processes. If an organisation has large amounts of data and transactions it is likely to influence its decision to adopt IT as this can help streamline operations and offer process efficiencies within the organisation (Poon and Joseph ,2000; Thong, Yap and Raman, 1996). The general feeling of the respondents was that their business operations and transactions were too small for e-commerce. 
According to Porter (200I), the profitability of businesses depends on the power they exercise over their partners, including suppliers and customers, and vice versa. Thus, enterprises seek to better position themselves in relation to their competitors. Thus enterprises endeavour to position themselves in relation to their clientele by offering better service through links with portals, e-mails, short message text (SMS) etc. However, the positioning of enterprises depends not only on the industry sector but also on factors such as: size of business, location of business, education level of business operators and other business players. Nevertheless, further research may be required to specifically address the correlation between these independent variables and e-commerce uptake as the present investigation has only provided a general picture of the current adoption of e-commerce and e-commerce enabling technologies.

In general, empirical results indicate that high cost, limited funds, lack of technical know-how and the nature of the organisation and its current ICT usage may influence e-commerce adoption. However, nearly all of the SME respondents consider the Internet and e-Commerce as important to business - both in the present and in the future. Among the perceived drivers of doing business through the Internet are: convenience and efficiency; the drive to be competitive in the industry in order to keep up with existing trends; necessity to access quality business information; and the attainment of customer satisfaction through improved interactions.

Lack of technical skills and awareness of the benefits of e-commerce may be mitigated through training and awareness creation programmes. It is also proposed that researchers in other less developed countries replicate the study so as to get a bigger picture of the current situation on ICT and e-commerce adoption in the SME sector. Further research should consider a study on SME business models and adoption of E-commerce drivers.

\section{References}

Ayyagari, M., Thorsten, B., Asli Demirgüç- Kunt. (2003). Small and Medium Enterprises across the Globe: A New Database. Documento de trabajo de Políticas de Estudio No. 3127. Banco Mundial, Washington, D.C.

Abell ,W. and Limm, L ( 1996). Business use of the Internet in New Zealand: an exploratory study. [Online] Available: http/l www.scu.edu.au/sponsored/ausweb96.[ Accessed ] 6 May 2005.

Akkeren, J. and Cavaye, A (1999). Factors affecting the adoption of e-commerce technologies by small business in Australia - an empirical study. [Online]. Available: www.acs.org.au/act/events/io/999/akkern.html. Accessed 8 April 2005

Bakos, Y. \& Brynjolfsson, E ( 2000). Bundling and Competition on the internet. Marketing Science, Vol I9, no. I, pp 63 - 82

Barry, H. \& Milner, B (2002). SME's and Electronic Commerce: A Departure from the Traditional Prioritisation of Training? Journal of European Industrial Training vol 25, no. 7, pp $316-326$

Blackburn, R. and Athayde, R (2000). Making the connection: the effectiveness of internet training in small businesses. Education and Training, Vol. 42, no. 4/5.

Bunker D.J. \& MacGregor R.C. (2000). Successful Generation of Information Technology (IT) Requirements for Small/Medium Enterprises (SME's) - Cases from Regional Australia Proceedings of SMEs in a Global Economy Wollongong, Australia, pp 72 84

CBS (2005). The economic survey, 2005

Chapman, P., James-Moore, M., Szczygeil, M. and Thompson, D. (2000) 'Building internet capabilities in SME's, Logistics Information Management, Vol. I3, No. 6, pp.353-360.

Chesher, M. and Skok, W. (2000) 'Roadmap for successful information technology transfer for small businesses, Proceedings of the 2000 ACM SIGCPR Conference on Computer Personnel Research, Chicago, Illinois, United States, pp. 16 -23.

Chen, L. Haney, S.; Pandzik, A. ; Spigarelli,,j; \& Jesseman, C ( 2003). Small business internet commerce: a case study, Information Resources Management Journal 16 (3), 2003, pp. 17-4I.

Crawford, J (1998). NEWS -A Project to get smaller enterprises online, Department of Industry, Science and Tourism, viewed March 23 2005, <http://www.noie.gov.au/publications/NOIE/SME/newsbk.pdf>.

Cyber Atlas (200I). Small business use net for customer service, communications, November 200I, available: http://cyberatlas. internet.com/markets/smallbiz/article/0,1009892 I82I,00.html Accessed on July 2005.

Daniel, E., Wilson, H., \& Myers, A (2002). Adoption of e-commerce by SME's in the UK: towards a stage model. International Small Business Journal, 20(3), 253-268.

Deloitte Touche Tohmatsu (2000) . Deloitte e-Business survey: insights and issues facing New Zealand business. Retrieved August 8, 2004 from the Web: http://www.deloitte.co.nz/images/acrobat/survey.pdf

Dennis C. (2000). Networking for Marketing Advantage Management Decision vol 38, no. 4, pp 287- 292

Doherty, N., Hughes, F. and Ellis-Chadwick, F. (200I). An investigation into the factors affecting the level of e-commerce uptake amongst SMEs. In Roberts, M., Moulton, M., Hand, S. and Adams, C. (eds) Sixth Annual Conference of UKAIS, Portsmouth, April (ZeusPress, Manchester), pp. 25I-7. School Press, Cambridge, MA).

Dutta, S. and Evrard, P. (1999). Information technology and organisation within European small enterprises. European Management Journal, 17(30), 239-51. York).

Engsbo, M., Saarinen, T., Salmi, H. \& Scupola, A ( 200I). "A framework of Adoption of E-Commerce in Networks of SMEs" in Proceedings of IRIS 200I, Ulvik, Norway.

Eurostat (200I). The European Community Survey on E-Commerce.

Fallon, M. \& Moran, P (2000). Information Communications Technology (ICT) and manufacturing SMEs 2000 Small Business and Enterprise Development Conference University of Manchester, pp 100 - 109

Hamill, J \& Gregory, K (1997). Internet marketing in the internationalisation of UK SMEs. Journal of Marketing Management, I3(I), 9-28. 
Hawkins P., Winter J. \& Hunter, J (1995). Skills for Graduates in the 2 Ist Century Report Commissioned from the Whiteway Research, University of Cambridge, Association of GraduateRecruiters, Cambridge

Hawkins ,P. \& Winter, J ( 1996). The Self Reliant Graduate and the SME Education and Training vol 38, no. 4, pp 3 - 9

Jacobs, G. \& Dowsland, W. (2000). The dot-com economy in Wales: the long road ahead. In Beynon-Davies, P; Williams, M.D. and Beeson, I (eds) UK Academy of Information Systems Conference, Swansea (McGraw-Hill, Maidenhead, UK), pp. 590-6.

Kagami, M. \& M. Tsuji (200I). The 'IT' Revolution and Developing Countries: Late-Comer Advantage.Institute of Developing Economies, Japan External Trade Organization, Tokyo.

Kendall, J., Lai, T. L., Chua, K. H., Ng, C. H. D. and Tan, S.M (200I). 'Electronic Commerce Adoption by SMEs in Singapore' Proceedings of 34th Hawaii InternationalConference on System Sciences, I-IO.

Khan E.H. \& Khan G.M.: (1992). Microcomputers and Small Businesses in Bahrain Industrial Management and Data Systems vol. 92, no. 6: pp $24-28$

Korchak, R \& Rodman, R (200 I). E-Business adoption among U.S. small manufacturers and the role of manufacturing extension. Economic Development Review, I7(3):20-25.

Knol, W.H.C. \& Stroeken, J.H.M (200I). "The Diffusion and Adoption of Information Technology in Small- and Medium - sized Enterprises through IT Scenarios”,Technology Analysis \& Strategic Management, Vol I3, no 2, pp 227-246.

Longenecker, , C. Moore, J. Petty ( 1997). Small Business Management: An Entrepreneurial Emphasis, SWC Publishing.

Martin L.M. \& Matlay H. (200I). "Blanket" Approaches to Promoting ICT in Small Firms: Some Lessons from the DTI Ladder Adoption Model in the UK Internet Research: Electronic Networking Applications and Policy vol . I I, no. 5, pp 399 - 4I 0

Matlay, H. (2000). Training in the Small Business Sector of the British Economy in Carter S. \& Jones D. Enterprise and Small Business: Principles, Policy and Practice Addison Wesley Longman, London

Mehrtens, J., Cragg, P.B. and Mills, A.M (200I). A Model of Internet Adoption by SMEs. Information and Management, Vol. 39, $165-176$

Michiels, S.I. and Van Crowder, L (200I). Discovering the 'Magic Box': Local Appropriation of Information and Communication Technologies (ICTs). SDRE, FAO, Rome.

MacGregor,R \& Vrazalic,L (2004). A Comparative Study of SMEs in Wollongong (Australia) and Karlstad (Sweden). School of Economics and Information Systems University of Wollongong [May 2004]

MacGregor R.C. \& Bunker D.J (1996b). The Effect of Priorities Introduced During Computer Acquisition on Continuing Success with It in Small Business Environments Information Resource Management Association International Conference Washington pp $27 \mid-277$

Miller, N.L. \& Besser T.L (2000). The Importance of Community Values in Small Business Strategy Formation: Evidence from Rural lowa Journal of Small Business Management vol 38, no. I, pp 68 - 85

Moed (2000b). E-Commerce: Building the strategy for New Zealand. Ministry of Economic Development, Wellington, New Zealand.

Mirchandani, D.A. \& Motwani, J. (200I). Understanding Small Business Electronic Commerce Adoption: An Empirical Analysis Journal of Computer Information Systems Vol. 4I, no. 3, pp $70-73$

Neergaard, P. (1992). Microcomputers in small and medium-size companies: benefits achieved and problems encountered Proceedings of the Third Australian Conference on Information Systems, Wollongong p 579 - 604

OECD (2004). Information and Communications Technologies. OECD Information technology Outlook.

O'Donnell, A., Gilmore, A. Cummins, D \& Carson, D (200I). The Network Construct in Entrepreneurship Research: A Review and Critique Management Decision vol 39, no. 9, pp 749 - 760

Oldfield, H. (2002). 'What SME's think', Quality World, Vol. 28, No. 6, pp. I0-I4.

Poon, S. and Swatman, P.M.C. (1999). An exploratory study of small business Internet commerce issues. Information and Management, 35(I), 9-18.

Poon, S. and Joseph, M. (2000) 'Product characteristics and internet commerce benefit amongst small businesses', Journal of Product \& Brand Management, Vol. 9, No. I, pp.2I-34.

Porter, M. (200I). Strategy and the Internet. Harvard Business Review March, pp 63 - 78

Poon S. \& Jevons C., (1997). "Internet-enabled International Marketing: a Small Business Network Perspective”, Journal of Marketing Management, Jan (26/I)

Poon, S. and Swatman, P (1997). Internet-Based small business communication. International Journal of Electronic Commerce, $7(2), 5-21$.

Pratt, J. H (2002). E-Biz.com: Strategies for Small Business Success, SBA advisory, Dallas, Texas.

Quayle M. (2002) E-commerce: The Challenge for UK SMEs in the Twenty-First Century International Journal of Operations and Production Management vol 22, no. 10, pp I I48 - I I6I

Raymond, L (200I) .Determinants of Web Site Implementation in Small Business Internet Research. Electronic Network Applications and Policy, Vol .I I, no. 5, 4I I - 422

Reynolds W., Savage W. \& Williams A. (1994). Your own business: A Practical guide to success ITP

Reedy, E.; Schullo, S.and Zimmerman,K ( 2000). Electronic marketing: Integrating Electronic Resources into the marketing process.Amazon.com.

Republic of Kenya [ROK] (1986). 'Sessional Paper No. I of 1986 on Economic Management for Renewed Growth’. Nairobi: Government Printer.

Ritchie, R. and Brindley, C (2000). Disintermediation, Disintegration and Risk in the SME Global Supply Chain. Management Decision, Vol .38, no. 8, pp $575-583$

Riquelme, H (2002). Commercial Internet Adoption in China: Comparing the Experience of Small, Medium and Large Business Internet Research. Electronic Networking Applications and Policy, Vol. I2, no. 3, 276 - 286

Rogers, E. M. (1983). The Diffusion of Innovations, New York: Free Press.

Rogers, E. M. (1995). Diffusion of Innovations, New York:Free Press.

SA Jnl Libs \& Info Sci 2006, 72(I) 
Scupola, A (2002). "Adoption Issues of Business-to-Business Internet Commerce in European SMEs", Proceedings of the 35th Hawaii International Conference on System Sciences, Hawaii, USA.

Smith A.J., Boocock G., Loan-Clarke J. \& Whittaker J. (2002). IIP and SMEs: Awareness, Benefits and Barriers Personnel Review, Vol 3I, no. I, pp $62-85$

Seyal, A. H. (2003). 'An Investigation of E-Commerce Adoption in Micro Business Enterprises: Bruneian Evidence', Proceedings of 4th International Conference on Working with e-Business (We-B 03), Perth, Western Australia, $24-25$ November.

Sharma, S. K. and Gupta, J. N. D. (2003). 'E-Commerce Adoption and Socio-Economic Influences: A Study in India', Proceedings of Fourth Annual Global Information Technology Management World Conference, Calgary,Canada, 8-10 June, Management, 39 , 4I5-29.

Sillince, J., Macdonald, S., Lefang, B. and Frost, B. (1998). Email adoption, use and impact within small. rms: a survey of UK companies. International Journal of Information Management, I8(4), 23 I-42.

Sawhney, M. \& Zabib J (2002). Managing and Measuring Relational Equity in the Network Economy .Journal of the Academy of Marketing Science Vol 30, no. 4, pp 313 - 332

Tetteh, E. and Burn, J (200I). Global Strategies for SME-business: Applying the SMALL Framework Logistics .Information Management, (14): 171 - 180

Turban E., King D, Lee J. Warkentin M \& Chung H.M (2002). Electronic Commerce Prentice Hall

Thong, J.Y.L., Yap C.S. and Raman, K.S (1996). Top Management Support, External Expertise and Information Systems Implementation in Small Business .Information Systems Research, Vol .7, no. 2, 248 - 267

UNIDO (2002). United Nations International Development Organisation, Partnership guide,Viena

Vescovi, T (2000). Internet Communication: The Italian SME Case. Corporate Communications: An International Journal, Vol. 5, no. 2, 107 - II 2

Walczuch R., Van Braven G. \& Lundgren H (2000). Internet Adoption Barriers for Small Firms in the Netherlands European Management Journal, Vol I8, no. 5, pp $56 \mathrm{I}-572$

Westland, J.C and Clark, T.H.K (1999). Global electronic commerce: theory and case studies [Online]. Available: http I43.89.56.92 (accessed 20 march 2005). 